\title{
FINANCIAL DISTRESS ANALYSIS OF INDONESIA RETAIL COMPANIES
}

\author{
Yelli Yulian \\ Magister of Management and Business, Business School, IPB University, Indonesia. \\ reginayulian1607@gmail.com \\ Idqan Fahmi \\ Department of Management and Business, Business School, IPB University, Indonesia. \\ ifahmi.mk@gmail.com \\ Tanti Novianti \\ Department of Economic, Faculty of Economic and Management, IPB University, Indonesia. \\ tantinovianti@yahoo.com
}

\begin{abstract}
ABSTRAK
Industri retail adalah industri yang kegiatan usahanya menyediakan produk dalam bentuk barang dan atau jasa kepada individu, diri sendiri, keluarga atau rumah tangga. Pada tahun 2016 dalam pengembangan retail global, tercatat bahwa Indonesia termasuk dalam 5 negara retail paling aktif serta berada di antara 5 negara dengan penjualan terbesar di Asia. Dalam beberapa tahun terakhir telah terjadi banyak penutupan gerai retail di Indonesia. Kondisi retail saat ini di Indonesia menghadapi banyak masalah, salah satunya adalah distorsi pendapatan baru, yaitu retail yang tidak memiliki tempat atau disebut perdagangan elektronik ( $E$ commerce). E-commerce melibatkan pembelian dan penjualan produk (seperti barang fisik, produk atau layanan digital) yang ditransaksikan melalui jaringan komputer. Penelitian ini menggunakan data dari 23 perusahaan untuk menggambarkan kondisi bisnis retail di Indonesia. Data dikumpulkan dari 2013 hingga 2017 dan dianalisis menggunakan regresi data panel dengan tiga pendekatan Altman, Springate dan Zmijewski. Semua perusahaan mengalami penurunan kinerja keuangan. Faktor-faktor yang mempengaruhi kesulitan keuangan adalah margin laba bersih, rasio saat ini, ukuran perusahaan dan total perputaran aset
\end{abstract}

Kata Kunci:

Ritel, Kesulitan Keuangan Perusahaan, Kinerja keuangan

\begin{abstract}
Retail industry is an industry whose business activities provide products in the form of goods and or services to individuals, themselves, families or households. In the past few years there have been many closures of retail outlets in Indonesia. In 2016 in global retail development, it was noted that Indonesia was included in the 5 most active retail countries as well as being among the 5 countries with the biggest sales in Asia. In recent years there have been many closures of retail outlets in Indonesia. The current retail condition in Indonesia faces many problems, one of which is the distortion of new income, namely retail that has no place or so-called electronic commerce (e-commerce). E-commerce involves buying and selling products (such as physical goods, digital products or services) that are transacted through computer networks.This study uses data from 23 companies to describe the condition of the retail business in Indonesia. Data collected from 2013 to 2017 and analyzed using panel data regression with three approaches Altman, Springate and Zmijewski. All companies experienced a decline in financial performance. The factors that influence the condition of financial distress are net profit margin, current ratio, size of firm and total asset turn over.
\end{abstract}

Keywords:

Retail, Financial Distress, Financial Performance. 


\section{INTRODUCTION}

Indonesia is a country that has great potential in business activities. This is based on the large population, according to a report from the Central Statistics Agency (2017) stating that the population of Indonesia there are 261.4 million people in Indonesia where from 2013 to 2017 increased by an average of 5.8 percent. Basically, the retail industry is an industry whose business activities provide products in the form of goods and or services to individuals, themselves, families or households. In 2016 in global retail development, it was noted that Indonesia was included in the five most active retail countries as well as being included in the five countries with the largest sales in Asia, which can be seen in Table 1.

Table 1. Sales Value and Global Retail Development Index 2016 Score

\begin{tabular}{lcc}
\hline Country & $\begin{array}{c}\text { Sales Value } \\
\text { (USD billion) }\end{array}$ & $\begin{array}{c}\text { Global Retail } \\
\text { Development } \\
\text { Index Score }\end{array}$ \\
\hline China & 3100 & 70.4 \\
India & 1100 & 71.7 \\
Indonesia & 350 & 55.9 \\
Malaysia & 92 & 60.9 \\
Vietnamese & 90 & 56.1 \\
\hline \multicolumn{2}{c}{ Source: AT Kearney (2016) }
\end{tabular}

The macro picture of the retail industry apparently cannot always be the basis for business people and investors to behave. Other information is needed that can provide a better picture related to retail conditions in Indonesia. Table 2 shows the development of retail in Indonesia from various categories.

Table 2. Retail Growth in Indonesia by Category (in percent)

\begin{tabular}{cccccc}
\hline Year & $\begin{array}{c}\text { Indon } \\
\text { esia }\end{array}$ & $\begin{array}{c}\text { Moder } \\
\mathbf{n} \\
\text { market }\end{array}$ & $\begin{array}{c}\text { Super } \\
\text { Marke } \\
\text { t }\end{array}$ & $\begin{array}{c}\text { Mini } \\
\text { Market }\end{array}$ & $\begin{array}{c}\text { Traditi } \\
\text { onal } \\
\text { market }\end{array}$ \\
\hline 2016 & 10.7 & 11.4 & 0.1 & 18.4 & 9.4 \\
2017 & 3.7 & 4.8 & 0.4 & 7 & 2.9 \\
\hline
\end{tabular}

Source: Alfaria Trijaya (2017)

Based on Table 3, it is known that retail in Indonesia experienced a slowdown in growth, in general the retail industry in Indonesia in 2016 could grow by 10.7 percent but in 2017 it would only grow by 3.7 . The slowdown affected almost all retail categories in Indonesia. It is known that the modern market has decreased by 6.6 percent from the previous year, minimarkets decreased by 11.4 percent and traditional markets dropped by 7.5 percent.

The importance of the retail industry in Indonesia has a very large role, explained that retail has a role in employment and economic growth. However, it was recorded from 2015 to 2017 that 9 retail companies out of 25 retail 
companies that were used as preliminary information had a downward trend.

Table 3. Percentage of Sales Growth and Profit Growth

\begin{tabular}{lrrrr}
\hline \multirow{2}{*}{ Code } & \multicolumn{2}{c}{ Sales Growth $(\boldsymbol{\%})$} & \multicolumn{2}{c}{ Profit Growth $(\%)$} \\
\cline { 2 - 5 } & $\mathbf{2 0 1 6}$ & $\mathbf{2 0 1 7}$ & $\mathbf{2 0 1 6}$ & $\mathbf{2 0 1 7}$ \\
\hline AMRT & 21.48 & 13.58 & 65.58 & -54.75 \\
DNET & 28.13 & 8.83 & -22.86 & -49.79 \\
HERO & -0.51 & -3.86 & 16.36 & -227.92 \\
LPPF & 32.14 & 10.62 & 79.08 & 15.52 \\
MAPI & 20.20 & 15.80 & 60.10 & 345.06 \\
MIDI & 27.10 & -6.24 & 72.84 & 7.87 \\
MPPA & 1.00 & -2.99 & -85.82 & -782.23 \\
RALS & 24.87 & 9.79 & 183.31 & 45.68 \\
RANC & 10.79 & 5.51 & 1029.68 & -31.69 \\
\hline
\end{tabular}

Source: Annual report (2016-2017) processed

In 2017, several important events occurred, such as 7 Eleven, which closed all of its business outlets due to being unable to compete and survive amid business changes. Lotus and Matahari are closing some of their outlets to protect the company's cash. This was confirmed by the closure of all Debenhams outlets in early 2018. From this a number of questions were drawn up including: 1) what kind of characteristics and financial performance of companies included in the retail sector on the Indonesia Stock Exchange?

2) How financial distress condition of each retail company on the Indonesia Stock Exchange? 3) What factors influence the financial distress of retail companies listed on
Indonesia Stock Exchange?

Retail is an effort to break up the goods or products that are produced and distributed by the manufacturer to be consumed by customers in small quantities according to their needs. Retail is the business activities of selling goods or services to individuals for the purposes of self, family, or household (Maruf 2016).

Financial distress is a condition which occurs in the company's financial problems, so that means the company's financial condition is not healthy or experiencing a critical (Platt \& Platt, 2002). Known financial problems due to many factors, such as investment mistakes, illiquid fund companies, companies that were late to innovate and the industry is not promising. A company's performance is a formal undertaking that describe the company that can later be used to evaluate and pursue the target company at a specific time period. (Jumingan, 2011) states that financial performance is a description of the condition of the company with a financial approach, the performance seen from a certain period. The company's financial performance is explained by (Sawir, 2001) which states that financial 
performance is a condition that reflects the financial condition of an enterprise based on goals and standards that have been set.

Inflation is the tendency for rising prices in general and continuously (Mankiw, 2006). Inflation occurs when price increases, general in nature, take place continuously occur simultaneously (Rahardja \& Manurung, 2004). Gross Domestic Product is a way to measure the market value of final goods and services produced by resources that are within a country during a certain period, usually one year . Gross domestic product calculation only includes final goods and services, the goods and services sold to final users .To goods and services purchased to be processed and then sold again not included in the count of GDP. Firm size is the size of the company is a measure of the size of a company is shown or judged by total assets, total sales, profit, tax expenses and others (Brigham \& Houston, 2007) .Interest or bank interest is a form of remuneration that is given to customers who buy or sell products. In Indonesia, the determination of the interest determined by Bank Indonesia. (Siamat, 2005) BI rate explains that the interest rate is one-month 218 tenor announced by Bank Indonesia periodically for a certain period of time that serves as a signal of monetary policy and announced to the public. Retailing in India is having problems is not well organized. From this the Indian government issued a policy to support retail has been organized in order accelerated economic growth (Gunjal 2017). Retail grouping is needed in order to strengths and weaknesses when menghapi an uncertainty (Chenchehene \& Mensah, 2014). On the other hand the study also describes an overview of how the company is able to recover from distress condition.

Retail can grow if you know the condition of the company and conditions beyond the company well. It is known from the ability to create solutions in anticipation of the possibility of unpredictable (Suryawardani, 2015). Retail is currently growing and require special attention to maintain growth (Sigh 2017). Predicts the company's financial condition is an important thing to do, it is intended for informational purposes in setting future strategy (Beaver, 2010). Describes in predicting financial distress must use approaches that match the characteristics of the 
company (Campbell, Hilscher, \& Szilagyi, 2008).

Financial distress models (Zmijewski, Altman, Springate) can be trusted to predict the condition of the company, where the level of trust is greater than 80 percent (Husein \& Pambekti 2015). Models can predict financial distress, but the springate model is said to be more accurate due to a smaller standard deviation (Meiliawati \& Isharijadi, 2017). Model has its own advantages in predicting financial conditions, in its research the zmijewski model is considered the most accurate in predicting possible financial problems (Wijaya \& Rasmini, 2015). When a company experiences financial problems, the current ratio will be below 1.1 and the debt ratio is above 1 (Ahmad, Basheer Hussein, Hassanudin, Md Yousuf, \& Nurun, 2014)

In this research, it is known that there are problems related to the condition of retail company performance which tends to decline. Information about the company is very important in providing good input for investors before making an investment decision, management usually gives a good picture so that the company remains selected by investors. In many studies explaining that only using the financial distress approach is considered sufficient to determine the condition of the company, but in this study using a measure of 4 important ratios (profitability, solvency, liquidity, activities) as the basis for information on the condition of the company's performance trends. Research conducted has a difference with other studies including the use of three methods in determining financial distress, followed by finding advantages and disadvantages of each approach.

\section{RESEARCH METHODS}

Data collection methods used in this study are non-probability sampling techniques with a purposive sampling approach. It is known that purposive sampling is a sampling technique that sets certain criteria in research. The research object criteria are (1) Retail companies that have been listed on the Indonesia Stock Exchange. (2) Retail companies have complete data from 2013 to 2017. (3) Data used in the form of annual reports

In this study using all retail companies 
that have criteria on predetermined sampling criteria. On this basis it is known that all companies fall into the predetermined categories so that they can be sampled in this study. There are 23 companies listed on the Indonesia Stock Exchange.

Table 4. Approach Financial Distress

\begin{tabular}{|c|c|c|}
\hline Approach & Formula & Limitation \\
\hline Altman & $\begin{array}{c}\mathrm{Z}=3.25+6.56 \\
\mathrm{MK} / \mathrm{TA}+3.26 \mathrm{P} / \\
\mathrm{TA}+6.72 \mathrm{EBIT} / \\
\mathrm{TA}+1.05 \mathrm{VME} / \\
\mathrm{VBL}\end{array}$ & $\begin{array}{c}\text { Z score }>2.6 \\
(\text { Safe }) \mid Z \\
\text { Score } 1.11<\mathrm{Z} \\
<2.6 \text { (Prone) } \\
Z \text { Z Score }<1.1 \\
\text { (Distress) }\end{array}$ \\
\hline Springate & $\begin{array}{c}\mathrm{S}=1.03 \mathrm{MK} / \mathrm{TA}+ \\
3.7 \mathrm{EBIT} / \mathrm{TA}+ \\
0.66 \mathrm{EBIT} / \mathrm{CL}+ \\
0.4 \mathrm{~S} / \mathrm{TA}\end{array}$ & $\begin{array}{c}\mathrm{S}>1,062 \\
(\text { Safe) } \mid 0862 \\
<\mathrm{S}<1,062 \\
\text { (Prone) } \mid \mathrm{S} \\
<0.862 \\
\text { (Distress) }\end{array}$ \\
\hline Zmijewski & $\begin{array}{c}\mathrm{X}=-4.3-4.5 \mathrm{NI} / \\
\mathrm{TA}+5.7 \mathrm{TL} / \mathrm{TA}- \\
0.004 \mathrm{CA} / \mathrm{CL}\end{array}$ & $\begin{array}{c}X>0 \\
\text { (Distress) } \mid X \\
<0 \text { (Safe) }\end{array}$ \\
\hline
\end{tabular}

This research will create a model with a panel data analysis approach. The model developed follows the approach of several previous researchers, while the model is summarized from several experts such as (Belloovary et al. 2007, Koleda \& Lace 2009), namely

$$
\begin{aligned}
& \mathrm{Y}=\alpha 1 \mathrm{CR}+\alpha 2 \mathrm{NPM}+\alpha 3 \mathrm{DER}+ \\
& \alpha 4 \mathrm{TATO}+\alpha 5 \mathrm{Inf}+\alpha 6 \mathrm{GDP}+ \\
& \alpha 7 \text { SIZE }
\end{aligned}
$$

$\mathrm{Y}=$ Financial distress ratio

$$
\begin{array}{ll}
\alpha 1-\alpha 8 & =\text { Constanta } \\
\mathrm{X} 1 & =\text { Current ratio } \\
\mathrm{X} 2 & =\text { Net profit margin } \\
\mathrm{X} 3 & =\text { Debt equity to ratio } \\
\mathrm{X} 4 & =\text { Total asset turn over } \\
\mathrm{X} 5 & =\text { Inflasi } \\
\mathrm{X} 6 & =\text { Gross domestic product } \\
\mathrm{X} 7 & =\text { Size Firm } \\
\mathrm{X} 8 & =\text { Interest }
\end{array}
$$

In the process of processing data distress financial research, will be assisted by Altman Z Score, Springate, Zmijewski and Regression Panel Data processed using software Eviews 9. The panel data regression analysis is divided into two namely static and dynamic. The advantage in using panel data is can control unobserved heterogeneity, provide informative, varied data, reduce colinearity, increase degrees of freedom, more complex and efficient behavioral models. The data processing methods used in this study include:

1. Pooled Least Square

PLS approach uses a combination of all data (pooled) so that the data used is $\mathrm{N} \mathrm{x}$ $\mathrm{T}$.

\section{Fixed Effect Model}

FEM model is a model that appears 
when between individual effects and explanatory variables have correlations or have patterns that are not random (Firdaus, 2012).

\section{Random Effect Model}

REM model is a model that appears when there is no correlation between individual effects and regressors.

\section{RESULTS AND DISCUSSION}

Retail business in Indonesia began to grow in the range of the 1980s. The growth of the retail industry in Indonesia is growing rapidly due to the growth that occurs in middle-class people who want to shop at supermarkets and department stores (convenience stores). The trend is then expected to continue in the days to come. Another thing that drives the development of retail business in Indonesia is the changing lifestyle of the upper middle class, especially in urban areas that tend to prefer shopping at modern shopping mall.

Retail industry in Indonesia is growing, illustrated by the increasing number of construction of new outlets in various places. It is visible through the activities of the investment made by retailers for the construction of new outlets is not difficult to understand. With an average economic growth of over 3\% since 2000 and more controlled inflation rate, they could be the reason that Indonesia could strengthen again in the future.

In the financial world enter the retail industry in the trade sector of the retail group. Type of business in the retail industry in the financial world is so diverse, it is because the retail business is defined as businesses that activity mainly dominated by sales of products in the unit (a small amount), in addition the products sold from any corporate entity can be a kind of fund diverse. Retail establishments or retail trading has diverse business activities and commodities traded. The grouping is based on the trading commodities such as daily needs (groceries), building materials and furniture, clothing and electronics. The times are so close to forcing the retailer's technology is also active in the online market. It is currently unknown 23 companies were used as research data only one company that does not use ecommerce market as the distribution of marketing their products. The development of the online market is very significant currently 
online market still has a marketshare of 6

percent of the total retail market in Indonesia..

Financial distress is important information for companies to know the condition of their financial and operational health. Information seeking related to the factors that influence the condition of financial distress is known, as a basis in predicting the health condition of the company. This research has identified several factors that influence the condition of financial distress, namely profitability ratio (NPM), liquidity ratio (CR), solvency ratio (DER), activity ratio (TATO), size of firm, inflation and gross domestic product.

The processing is done using panel data with all retail companies listed on the Indonesia Stock Exchange. In order to obtain the best model, a test is carried out with a number of requirements as required by panel data testing, information is presented in Table 5.

Table 5. Selection of the Best Model

\begin{tabular}{lccc}
\hline $\begin{array}{l}\text { Testing } \\
\text { parameters }\end{array}$ & Altman & Springate & Zmijewski \\
\hline Chow Test & 0.0002 & 0.0934 & 0.0000 \\
Hausman & 1 & 1 & 1 \\
Test & & & \\
Information & FEM & PLS & FEM \\
\hline
\end{tabular}

Table 6. Factors Affecting Financial Distress from Three Approaches

\begin{tabular}{cccc}
\hline Variable & Altman & Springate & Zmijewski \\
\hline C & -39.80 & - & 32.77 \\
NPM & $\mathbf{0 . 7 0}$ & $\mathbf{0 . 2 5}$ & $\mathbf{- 0 . 4 7}$ \\
CR & $\mathbf{4 . 0 2}$ & $\mathbf{0 . 3 2}$ & $\mathbf{- 1 . 6 4}$ \\
DER & 0.84 & 0.04 & 0.10 \\
TATO & -0.84 & $\mathbf{0 . 3 7}$ & -0.32 \\
SIZE & $\mathbf{1 . 7 1}$ & -0.01 & $\mathbf{- 1 . 1 6}$ \\
INF & 0.94 & 0.04 & -0.02 \\
GDP & -1.96 & -0.01 & -0.07 \\
R-squared & 0.62 & 0.31 & 0.75 \\
\hline
\end{tabular}

Based on the results of processing with the three approaches, it is found that several important variables have a significant influence on the company's health condition. This is explained in Table 7, where there is a similarity in each approach, namely the Net Profit Margin variable which is an embodiment of profitability ratios and Current Ratio which is an embodiment of liquidity ratios. On the other hand it is known that size of firm is an important variable in the Altman and Zmijewski approach while in the springate approach the important variable is Total Asset Turn Over.

Table 7. Variables Affecting the Financial Distress Conditions of Each Approach

\begin{tabular}{lccc}
\hline Approach & Altman & Springate & Zmijewski \\
\hline Variable & $\begin{array}{c}\text { NPM, } \\
\text { CR, Size } \\
\text { of Firm }\end{array}$ & NPM, CR & NPM, CR, \\
& & $\begin{array}{c}\text { Size of } \\
\text { Firm }\end{array}$ \\
\hline
\end{tabular}

Net profit margin is an important variable that describes the condition of the company's net income, if the company still has 
a net profit it means that the company is still able to pay all obligations. Yadiati (2017) explains that profitability (NPM) has a real influence on the health condition of the company through the measurement of altman, this is due to the fact that profit becomes an important thing that can influence the company for operational activities and investment in the future. Maturunggan etal. (2017) profitability ratios have a big influence on the company's financial condition. The value of the NPM indicates that the company is operating more efficiently. The company can reduce unnecessary costs, so the company is able to maximize the net profit obtained.

Current ratio is an illustration related to the company's ability to pay all short-term financial obligations at maturity using available current assets. The greater the $\mathrm{CR}$ value of a company, the financial condition of the company will be healthier and far from problems. Eternal diploma (2013) explains that the current ratio has a significant effect on the company's financial health. This is due to the ability to pay current debts is an important thing in the company's activities. On the other hand the current ratio gives a picture of the guaranteed relationship of corporate debts to creditors.

Total asset turn over has a positive value of 0.366 which means that the greater the company's assets turnover, the impact on the healthier the company. The retail industry is basically very closely related to asset turnover, where huge profits can be created because of the rapid product turnover Size of firm is a picture of a company that has a large total assets shows that the company has reached the stage of maturity in which at this stage the company's cash flow is positive and is considered to have good prospects in a relatively long period of time, while also reflecting that the company is relatively more stable and more capable generate profits compared to companies with small total assets (Basuki,2006). It is known that the output value is 0.087 which means that the larger the size of the company, the healthier the company. Rianti and Yadiati (2018) explained that they have an influence on financial distress, but this still needs further study where looking at the level of use of assets from companies to benefit. 
From Table 7 it can be said that each approach does not have a large difference in terms of variables that affect health conditions. Management can use together from each approach in order to carry out conservative activities to find out the actual condition of the company's financial health. But information is needed related to the best approach to determine the condition of financial distress. When referring to each approach several strengths and weaknesses are found, which can support that the model can be used together, as described in Table 8.

When referring to the history of the financial distress approach, the Altman approach (1968) was developed with the Multiple Discriminant Analysis technique, altman was originally used to predict financial difficulties from company tips, at first altman was general but continued to be developed into several types such as for manufacturing, nonmanufacturing and companies in emerging markets. Springate was developed in 1978 to be used to see indications of bankruptcy in manufacturing companies in Canada. The Zmijewski approach is an approach developed in 1984, which is based on the use of several 224 external factors such as company size and economic cycles.

Table 8. Strengths and Weaknesses of the Altman, Springate and Zmijewski approach

\begin{tabular}{|c|c|c|c|}
\hline $\begin{array}{c}\text { Descri } \\
\text { ption }\end{array}$ & Altman & Springate & Zmijewski \\
\hline $\begin{array}{l}\text { Advant } \\
\text { ages }\end{array}$ & $\begin{array}{l}\text { - Focus on } \\
\text { asset } \\
\text { growth } \\
\text { - The } \\
\text { company } \\
\text { assumes } \\
\text { that } \\
\text { profits } \\
\text { will grow } \\
\text { with the } \\
\text { growth of } \\
\text { assets. }\end{array}$ & $\begin{array}{l}\text { - Focus on } \\
\text { profit } \\
\text { growth. } \\
\text { - Efficienc } \\
\text { y is } \\
\text { importan } \\
\text { t for } \\
\text { company } \\
\text { health } \\
\text { - Maintain } \\
\text { current } \\
\text { liability } \\
\text { position } \\
\text { so as not } \\
\text { to } \\
\text { exceed } \\
\text { current } \\
\text { assets. }\end{array}$ & $\begin{array}{l}\text { - Net } \\
\text { income is } \\
\text { very } \\
\text { important } \\
\text { to note. } \\
\text { - Efficient in } \\
\text { managing } \\
\text { costs is } \\
\text { important } \\
\text { - The } \\
\text { compositio } \\
\mathrm{n} \text { of the } \\
\text { liability is } \\
\text { maintained }\end{array}$ \\
\hline $\begin{array}{l}\text { Weakn } \\
\text { ess }\end{array}$ & $\begin{array}{l}\text { - Can only } \\
\text { be used } \\
\text { for Public } \\
\text { Companie } \\
\text { s } \\
\text { - Does not } \\
\text { accommo } \\
\text { date } \\
\text { sources of } \\
\text { asset } \\
\text { growth. }\end{array}$ & $\begin{array}{l}\text { - Don't } \\
\text { see } \\
\text { compan } \\
\text { y } \\
\text { growth } \\
\text { as } \\
\text { importa } \\
\text { nt }\end{array}$ & 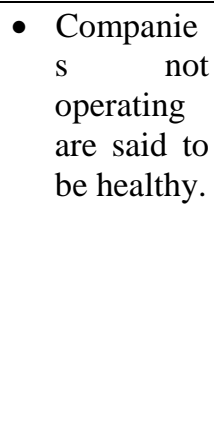 \\
\hline
\end{tabular}

Zmijewski is an approach to find out the best financial distress condition used in research, this is based on the highest Rsquare value of Eviews output. Wulandari and Julita (2013) explained that Rsquare can be used as a basis for drawing conclusions related to the best model used in research. Rismawaty (2012) states the Zmijewski model is the most suitable model applied to companies in 
Indonesia because the level of accuracy is the highest compared to other prediction models.

In this study it is known that there are several managerial implications that need to be considered by management. This is due to the very large impact of financial distress for the company if the company has experienced financial problems. These include:

\section{a. Company Characteristics}

Information on the characteristics of the company is an important thing that can be used as an illustration of the ability of business endurance to deal with market uncertainty that occurs. Companies should start thinking about diversifying their funds or collaboration with other companies in order to maintain sales. Implementation that can be done from the company is conducting joint operations in businesses that are run in accordance with the core business of each company.

b. Improved Financial Performance Companies experiencing financial problems can make financial improvements through refinancing. On the other hand, the decline in financial performance was largely due to an increase in cost of production and operational costs. Companies need to make efficiency of every expenditure made, this is as a form of prevention from the increase in costs that can not be predicted.

c. Predictions of the Company's Financial Health

Retail companies must always calculate financial health. It is intended that the company is able to get a warning if there are symptoms of financial difficulties due to decreased operational performance. This is an early warning for companies in order to maintain the financial health of the company

\section{CONCLUSION}

AND

\section{RECOMMENDATION}

In this study has several conclusions related to the purpose of the research conducted, as for among others: The characteristics of companies in the retail sector on the Indonesia Stock Exchange basically can 
be divided based on the main business groups that are carried out such as daily necessities (groceries), building materials and furniture, clothing and electronics.

The condition of the company's financial performance in the retail sector on the Indonesia Stock Exchange is very diverse, this is based on differences in business characteristics and management activities carried out by the company but can on average the conditions of each company decline every time. The condition of financial distress in the retail sector on the Indonesia Stock Exchange apparently occurred in almost all companies, this indicates that there are big symptoms in retail in Indonesia, as for companies experiencing financial health conditions namely COIN, HERO, RANC, MPPA, RIMO, DUTA, CENT, ECCI, GLOB, SKYB, GOLD, KIOS and TRIO.

The variables that affect the financial distress of each approach are the Altman approach (Current Ratio, Net Profit Margin and Size of Firm), the Springate approach (Current Ratio, Net Profit Margin and Total Asset Turn Over) and the Zmijewski approach (Current Ratio, Net Profit Margins and Size of 226
Firm).

Suggestions related to the research are: In this study examines the holding business of a retail company, additional information is needed related to other activities described by the subsidiary.In the research model, it is necessary to add macro variables to determine the effect of financial distress on each retail company. 


\section{REFERENCES}

Ahmad, K., Basheer Hussein, M. A., Hassanudin, M. T. T., Md Yousuf, H., \& Nurun, N. (2014). Identifying Financial Distress Firms: A Case Study of Malaysia's Government Linked Companies ( GLC ). International Journal of Economic, Finance and Management, 3(3), 141150.

Altman, E. I. (1968). Financial ratios, discriminant analysis and the prediction of corporate bankruptcy. The Journal of Finance. https://doi.org/10.1111/j.1540- 6261.1968.tb00843

Badan Pusat Statistik. (2017). Indikator Ekonomi. Buletin Statistik Bulanan. https://doi.org/10.1002/jgrd.50612

Brigham, E. F., \& Houston, J. F. (2007). Fundamentals of financial management (Dasar-dasar Manajemen Keuangan). In Engineering and Process Economics. https://doi.org/10.1038/sj.ejhg.5200824

Campbell, J. Y., Hilscher, J., \& Szilagyi, J. (2008). In search of distress risk. Journal of Finance. https://doi.org/10.1111/j.1540-6261.2008.01416

Chenchehene, J., \& Mensah, K. (2014). Corporate Survival: Analysis of Financial Distress and Corporate Turnaround of the UK Retail Industry. International Journal of Liberal Arts and Social Science.

Gunjal, T. D. (2017). a Swot Analysis and Recent Fdi Controversy of Retail Sector in India. Research Journal of Multidisciplinary Studies, 3(4), 2454-8499.

Husein, M. F., \& Pambekti, G. T. (2015). Precision of the models of Altman, Springate, Zmijewski, and Grover for predicting the financial distress. Journal of Economics, Business \& Accountancy Ventura, 17(3), 405. https://doi.org/10.14414/jebav.v17i3.362

Jumingan. (2011). Pengaruh Rasio Likuiditas, Rasio Leverage Dan Rasio Aktivitas Terhadap Kinerja Keuangan Perusahaan. Jurnal Administrasi Bisnis.

Mankiw, N. G. (2006). The macroeconomist as scientist and engineer. Journal of Economic Perspectives. https://doi.org/10.1257/jep.20.4.29

Maruf, H. (2006). Pemasaran Ritel. In Jakarta: Gramedia Pustaka Utama. https://doi.org/10.1007/s10872-006-0051-9

Machmud, Senen \& Wijanarko Bambang Agus (2013). Yadiati, W. (2017). The Influence Of Profitability On Financial Distress: A Research On Agricultural Companies Listed In Indonesia Stock Exchange. Jurnal Ekonomi, Bisnis \& Entrepreneurship 7(1): 30-40.

Meiliawati, A., \& Isharijadi, I. (2017). Analisis perbandingan model springate dan altman z score terhadap potensi financial distress (studi kasus pada perusahaan sektor kosmetik yang terdaftar di bursa efek indonesia). Assets: Jurnal Akuntansi Dan Pendidikan. https://doi.org/10.25273/jap.v5i1.1183

Moeller, S. B., Schlingemann, F. P., \& Stulz, R. M. (2004). Firm size and the gains from acquisitions. Journal of Financial Economics. https://doi.org/10.1016/j.jfineco.2003.07.002

Naz, F., Ijaz, F., \& Naqvi, F. (2016). Financial Performance of Firms: Evidence From Pakistan Cement Industry. Journal of Teaching and Education.

Organised Retailing- A SWOC Analysis. (2017). 4(3). 
Platt, H. D., \& Platt, M. B. (2002). Predicting corporate financial distress: Reflections on choice-based sample bias. Journal of Economics and Finance. https://doi.org/10.1007/bf02755985

Rahardja, P., \& Manurung, M. (2010). Kebangkrutan Perusahaan Menggunakan Model Altman Dan Zavgren Pada Perusahaan Food And Beverages. 11(1) : 12- 25

Rahmawati \& Agustina Y. (2004). Teori Ekonomi Makro: Suatu Pengantar. Edisi Ketiga. Lembaga Penerbit FE-UI. https://doi.org/10.1146/annurev.ento.48.091801.112645

Rianti, I. P., \& Yadiati, W. (2018). How financial distress influence by firm size. International Journal of Scientific and Technology Research.

Rohimman, Sabrina Firdausi. \& Damayanti, Cacik Rut. (2019). Pengaruh Inflasi, Nilai Tukar Dan Suku Bunga Terhadap Financial Distress (Studi Pada Semua Perusahaan Yang Terdaftar Di Bursa Efek Indonesia Periode 2013- 2017). Jurnal Administrasi Bisnis. 72(2) : 186-196

Sawir, A. (2001). AnalisisKinerja Keuangan danPerencanaan Keuangan Perusahaan. PT Gramedia Pustaka Utama. https://doi.org/10.1021/j100193a062

Siamat, D. (2005). Manajemen Lembaga Keuangan. “Kebijakan Moneter dan Perbankan.” In Jakarta: Fakultas Ekonomi Universitas Indonesia, edisi kesatu. https://doi.org/10.1515/ci.2005.27.6.25

Suryawardani, B. (2015). Analisis perbandingan kemampuan prediksi kebangkrutan antara analisis altman, analisis ohlson dan analisis zmijewski pada sektor industri tekstil yang go public di bursa efek indonesia periode 2008-2012. Ecodemica.

W. H. Beaver, M. C. and M. F. M. (2010). Financial Statement Analysis and the Prediction of Financial Distress, Foundation and Trends in Accounting.

Wijaya, E., \& Rasmini, N. (2015). Pengaruh audit fee, opini going concern, financial distress, ukuran perusahaan, ukuran kap pada pergantian auditor. E-Jurnal Akuntansi.

Yadiati, W. (2017). The Influence Of Profitability On Financial Distress: A Research On Agricultural Companies Listed In Indonesia Stock Exchange. Journal of Scientific \& Technology Research. 